\title{
Contiguous rather than discrete Paleozoic histories for the Avalon and Meguma terranes based on detrital zircon data
}

\author{
J. Brendan Murphy Department of Earth Sciences, St. Francis Xavier University, Antigonish, Nova Scotia B2G 2W5, Canada \\ Javier Fernández-Suárez Departamento de Petrología y Geoquímica, Universidad Complutense, 28040 Madrid, Spain \\ J. Duncan Keppie Instituto de Geología, Universidad Nacional Autónoma de México, México D.F. 04510, Mexico \\ Teresa E. Jeffries Department of Mineralogy, Natural History Museum, Cromwell Road, London SW7 5BD, UK
}

\begin{abstract}
Upper Ordovician-Lower Devonian strata of the Meguma terrane in the Canadian Appalachians contain zircon populations, including an important Mesoproterozoic zircon population (1.0-1.4 Ga), similar to those in coeval strata of Avalonia, and strongly suggest contiguous rather than discrete histories for these terranes throughout the Paleozoic. That these terranes were juxtaposed throughout the early Paleozoic is indicated by the absence of a Cambrian-Ordovician accretionary event, the lack of intervening suture-zone ophiolitic units, and the similarity of Avalonian and Meguma basement Nd isotope signatures in early Paleozoic igneous suites. As Avalonia had accreted to Laurentia-Baltica by the Early Silurian, these data suggest that the Meguma terrane, like Avalonia, resided along the same (northern) margin of the Rheic Ocean at that time. These conclusions have implications for reconstructions of the northern Gondwanan margin in the early Paleozoic and imply that the Silurian-Devonian Acadian orogeny in Maritime Canada occurred in an Andean-type setting and was not related to collision of the Meguma terrane with the Laurentian margin.
\end{abstract}

Keywords: Meguma terrane, Avalonia, Appalachian orogen, Acadian orogeny.

\section{INTRODUCTION}

Evidence that might establish the original relationship between adjacent terranes and determine their time of amalgamation is often obscured or overprinted by subsequent tectonothermal events. The long-standing controversy about the original relationship between the Avalon and Meguma terranes in the Paleozoic Appalachian orogen is an example of such a problem. Two rival hypotheses have emerged: (1) these terranes developed along different parts of the Gondwanan margin in the late Neoproterozoic and were accreted to Laurentia as separate terranes and the accretion of Avalonia and/or the Meguma terrane was related to the Devonian Acadian orogeny (e.g., Schenk, 1997; Robinson et al., 1998); (2) Meguma terrane rocks were deposited on Avalonian basement along the same part of the Gondwanan margin, traveled as a single tectonic unit, and together were accreted to Laurentia-Baltica by the Early Silurian (e.g., Keppie et al., 1997).

Resolution of this controversy is fundamental to the understanding of the development of the orogen, the relationship between terrane accretion and orogenic events, and the paleogeography of the Iapetus and Rheic Oceans, which were between Laurentia and Gondwana. However, paleomagnetic and faunal data are equivocal. Early-Middle Silurian fauna are cosmopolitan and Rhenish fauna were present in both Avalonia and the Meguma terrane in the Late Silurian and gradually invaded the rest of the Canadian Appalachians through the Early Devonian (Boucot, 1975). Comparison between the stratigraphy and provenance of coeval Late Ordovician-Early Devonian sequences on neighboring terranes is a key to solving this controversy. We present laserablation-inductively coupled plasma-mass spectrometry U-Pb data (see FernándezSuárez et al., 2002; Jeffries et al., 2003) on detrital zircons from two samples in the Upper Ordovician and Lower Devonian clastic sedimentary rocks in the Meguma terrane (Fig. 1) and compare these data with detrital zircon data from coeval strata in Avalonia.

\section{GEOLOGIC SETTING}

The Appalachian-Caledonide orogen was formed by the accretion of suspect terranes to Laurentia-Baltica at various times during the Ordovician-Devonian, followed by collision with Gondwana and the formation of Pangea in the Carboniferous-Permian (e.g., van Staal et al., 1998). The Meguma terrane is the farthest outboard terrane in the Northern Appalachians. It is exposed only in mainland Nova Scotia (Fig. 1) and is separated from the Avalon terrane to the north by a fault zone (the Minas fault zone, MFZ, Fig. 1), which is widely acknowledged to have had repeated episodes of strike-slip movement in the late Paleozoic (e.g., Keppie et al., 1997). The Meguma terrane is predominantly underlain by thick Cambrian-Ordovician turbidites of the Meguma Group containing Gondwanan fauna (Pratt and Waldron, 1991). These rocks are disconformably to unconformably overlain by Upper Ordovician to Lower Devonian bimodal volcanic and shallow-marine to continental clastic rocks (Silurian White Rock and Lower Devonian Torbrook Formations with Rhenish-Bohemian fauna; Boucot, 1975). The mid-Late Ordovician switch from turbidites to shallow-marine deposits was accompanied by a change from a southerly to a northerly source. Detrital zircons in the Goldenville Formation (lower unit of the Meguma Group) yielded ca. 3.0 Ga, 2.0 Ga, and $600 \mathrm{Ma}$ ages, indicating a Gondwanan (West Africa) source prior to separation (Krogh and Keppie, 1990). During the Acadian orogeny, these rocks were deformed, metamorphosed, and intruded by late syntectonic Late Devonian (ca. 375-370 Ma) granitoids (Clarke et al., 1993).

Many authors have inferred that the Meguma Group represents a Cambrian-Early Devonian passive margin bordering northwest Africa that was transferred to Laurentia during the Acadian orogeny (e.g., Schenk, 1997). This interpretation is based primarily upon (1) proposed correlations between the CambrianSilurian strata in the Meguma terrane and coeval sequences in Morocco and (2) the Middle Devonian age of the Acadian orogeny, the oldest accretionary event recognized in the Meguma terrane. If so, Meguma terrane Cambrian-Lower Devonian rocks would have a Gondwanan source, but Middle Devonian rocks would have an Avalonian-Laurentian provenance. Alternatively, the CambrianLower Devonian strata of the Meguma terrane may represent a passive margin deposited on Avalonian continental crust (e.g., Keppie et al., 1997). This interpretation is based upon (1) the proposed correlation of the Upper Ordovician-Lower Devonian units in the Meguma terrane with coeval sequences in the Appalachians (Keppie and Krogh, 2000) and (2) the similarity of $\mathrm{Nd}$ isotope signatures in Late Ordovician-Early Silurian crust-derived igneous suites in the Meguma and Avalon terranes (Keppie et al., 1997). As these suites predate the Acadian orogeny, and no older deformational events are recorded, the data indicate that the Meguma Group was deposited on Avalonian basement (Keppie et al., 2003). 
Figure 1. Early Mesozoic location of West Avalonia, Meguma, and related peri-Gondwanan terranes and location of Ordovician-Silurian sequences. West Avaloniaperi-Gondwanan rocks in Atlantic Canada and New England (modified from Keppie et al., 2003). Inset shows map of Appalachian orogen in Maritime Canada and Maine. MFZ-Minas fault zone, which defines boundary between West Avalonia and Meguma terranes. Bottom right: Summary of Silurian-Emsian stratigraphy of Arisaig Group (West Avalonia) and Annapolis Valley (Meguma).

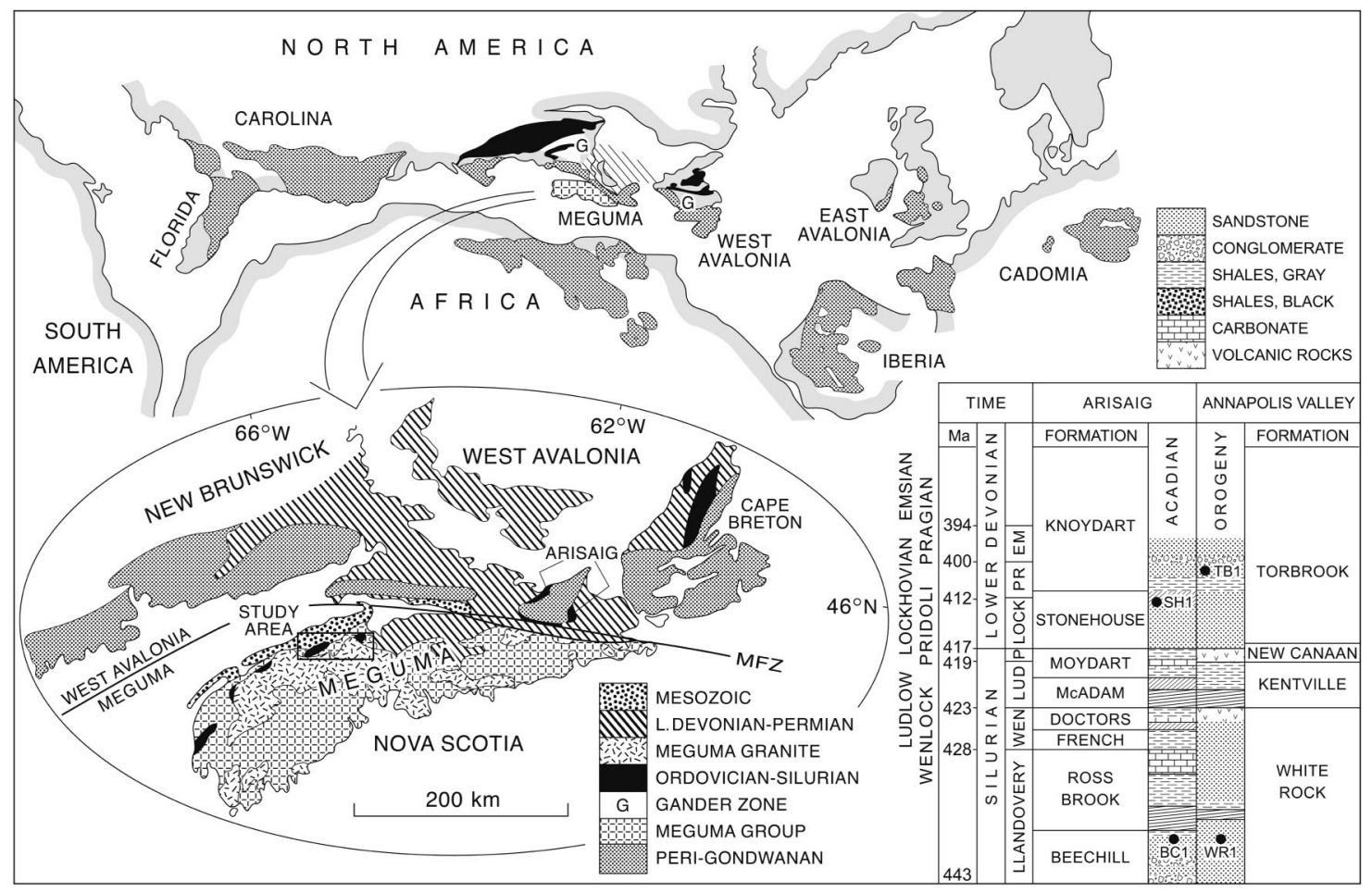

If so, Cambrian-Middle Ordovician Meguma strata should display evidence of a connection to Gondwana, but the Late Ordovician-Early Silurian, Meguma terrane rocks should show an Avalonian-Laurentian-Baltican source.

\section{ANALYTICAL TECHNIQUES}

Analytical instrumentation, analytical protocol and methodology, data reduction, age calculation, and common $\mathrm{Pb}$ correction are as described in Fernández-Suárez et al. (2002) and Jeffries et al. (2003). In this study, nominal laser-beam diameter was $30 \mu \mathrm{m}$ for zircon analyses of sample WR-10, but all zircons from sample TB-1 were analyzed with a nominal beam diameter of $18 \mu \mathrm{m}$ owing to their small size.

Data were collected in discrete runs of 20 analyses, comprising 12 unknowns bracketed before and after by 4 analyses of the standard zircon 91500 (Wiedenbeck et al., 1995). During the analytical sessions of samples WR-10 and TB-1, the standard 91500 yielded a weighted mean $(n=56)$ of $1062.3 \pm 1.9 \mathrm{Ma}$ (mean square of weighted deviates [MSWD] $=1.2$ ) for the ${ }^{206} \mathrm{~Pb} /{ }^{238} \mathrm{U}$ age (certified isotope dilution thermal ionization mass spectrometry [ID-TIMS] ${ }^{206} \mathrm{~Pb} /{ }^{238} \mathrm{U}$ age: $1062.4 \pm 0.4 \mathrm{Ma}$ ) and a weighted mean of $1065.3 \pm 2 \mathrm{Ma}$ $\left(\mathrm{MSWD}=0.6\right.$ ) for the ${ }^{207} \mathrm{~Pb} /{ }^{206} \mathrm{~Pb}$ age (certified ID-TIMS ${ }^{207} \mathrm{~Pb} /{ }^{206} \mathrm{~Pb}$ age: $1065.4 \pm 0.3$ $\mathrm{Ma})$. Concordia age calculations, and creation of concordia and cumulative probability plots, were performed by using Isoplot/Ex rev. 2.49 (Ludwig, 2001).

\section{RESULTS}

Of 84 analyses (1 analysis per grain) performed on zircons from samples WR-10 (48 analyses) and TB-1 (36 analyses), 23 were rejected (14 in WR-10 and 9 in TB-1) because of the presence of features such as discordance $>20 \%$, high common $\mathrm{Pb}$ detected in the $\mathrm{U}$ $\mathrm{Pb}$, Th- $\mathrm{Pb}$, or $\mathrm{Pb}-\mathrm{Pb}$ isotope ratio plots, elemental U-Pb fractionation, or inconsistent behavior of $\mathrm{U}-\mathrm{Pb}$ and $\mathrm{Th}-\mathrm{Pb}$ ratios in the course of ablation (see Jeffries et al., 2003). Detailed methodology, $\mathrm{U}-\mathrm{Pb}$ and $\mathrm{Pb}-\mathrm{Pb}$ ratios, and ages for the 61 selected analyses are available. ${ }^{1}$ Figure 2A shows age histograms for the two samples, and concordia plots for each sample are presented in Figures $2 \mathrm{~B}$ and 2C.

Sample WR-10 (Fig. 2B) from near the base of the White Rock Formation yielded five zircons with Cambrian-Neoproterozoic ages $(542 \pm 12$ to $551 \pm 10 \mathrm{Ma})$. Of 18 zircons that have Neoproterozoic ages, 15 are between $560 \pm 28$ and $640 \pm 10 \mathrm{Ma}$, and 3 yielded ages of $681 \pm 9,830 \pm 8$, and 838 \pm 29 Ma. Six zircons yielded Mesoproterozoic ages of $986 \pm 18,1047 \pm 11,1186 \pm$ $12,1200 \pm 16,1211 \pm 12$, and $1234 \pm 13$ Ma. Five zircons yielded a cluster of Paleoproterozoic ages, $1941 \pm 10,2026 \pm 16$, $2078 \pm 22,2092 \pm 19$, and $2188 \pm 14 \mathrm{Ma}$.

${ }^{1}$ GSA Data Repository item 2004094, Analytical techniques and Table DR1, zircon data, is available online at www.geosociety.org/pubs/ft2004.htm, or on request from editing@geosociety.org or Documents Secretary, GSA, P.O. Box 9140, Boulder, CO 80301-9140, USA.
Sample TB-1 (Fig. 2C) from the top of the Torbrook Formation yielded five Paleozoic zircons, two Early Devonian-Middle Devonian $(388 \pm 8$ and $397 \pm 6 \mathrm{Ma})$, one Late Ordovician (444 $\pm 8 \mathrm{Ma}$ ), and two Cambrian $(524 \pm 10$ and $533 \pm 11 \mathrm{Ma})$ ages. One zircon yielded an age near the CambrianNeoproterozoic boundary (547 $\pm 8 \mathrm{Ma})$. Nine zircons yielded Neoproterozoic ages between $602 \pm 6$ and $826 \pm 8 \mathrm{Ma}$; of these, five zircons are younger than $630 \pm 9$ Ma (Table DR1; see footnote 1). Four zircons yielded Mesoproterozoic ages of $1018 \pm 12,1073 \pm$ $13,1174 \pm 38$, and $1440 \pm 30 \mathrm{Ma}$, and seven zircons yielded Paleoproterozoic ages of 1762 $\pm 18,1786 \pm 40,1864 \pm 20,2002 \pm 26$, $2078 \pm 25,2134 \pm 24$, and $2176 \pm 16 \mathrm{Ma}$. One zircon (not shown in Fig. 2C) yielded a concordant Archean age of $2727 \pm 15 \mathrm{Ma}$.

\section{TECTONIC SIGNIFICANCE}

A comparison between the U-Pb detrital zircon ages of the samples and the ages of tectonothermal events in potential source areas is shown in Figure 3. In general the detrital zircons in the White Rock and Torbrook Formations are similar to one another, to detrital zircon ages from the Silurian-Lower Devonian Arisaig Group, and to detrital zircon ages from Neoproterozoic rocks of Avalonia in Maritime Canada (Keppie et al., 1998). In contrast, detrital zircon data from the underlying Cambrian rocks of the Meguma Group are characterized by the absence of 1900-700 Ma detrital zircons. Taken together, these data 

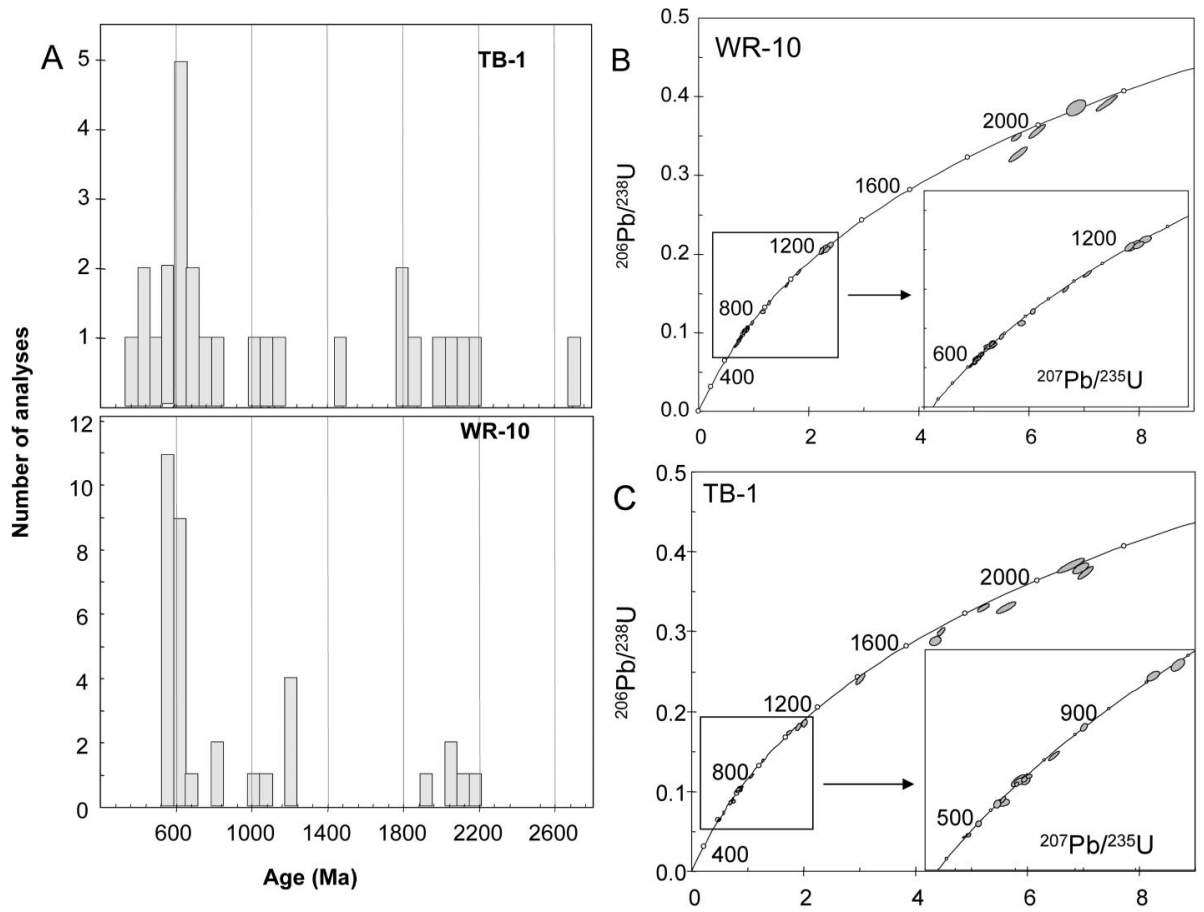

Figure 2. Laser-ablation-inductively coupled plasma-mass spectrometry data from WR-10 and TB-1. A: Histogram of zircon ages from two samples analyzed. Ages and errors used are those reported in Table DR1 (see footnote 1 in text). B: U-Pb concordia plots for analyses of sample WR-10. C: U-Pb concordia plots for analyses of sample TB-1 (ellipses in $B$ and $C$ represent $2 \sigma$ uncertainties).

suggest that the Meguma terrane was adjacent to Avalonia in the Late Ordovician-Early Silurian, and are consistent with sedimentological studies in the White Rock Formation that indicate a shoreline to the north (present coordinates) in the Early Silurian (Lane, 1976). By this time, Avalonia had accreted to Laurentia-Baltica, a conclusion supported by paleomagnetic (MacNiocaill et al., 1997) and faunal data (Williams et al., 1995) and by the geochemical and $\mathrm{Nd}$ isotope signatures of the basal Silurian rocks in adjacent Avalonia that indicate derivation from an ancient (nonAvalonian) cratonic basement (Murphy et al., 1996, 2004). This relationship implies that the White Rock and Beechill Cove Formations are part of a postaccretionary clastic sequence that overstepped terrane boundaries, and that the juxtaposition of Laurentia-Baltica with both the Avalon and Meguma terranes occurred by ca. 440 Ma. Thus, the detrital zircons may have been derived either directly from a basement source in Baltica-Laurentia or recycled from Avalonian sediment (Fig. 3). The proposed Meguma-Avalon connection is consistent with $\mathrm{Sm}-\mathrm{Nd}$ isotope data for the crustderived felsic volcanic rocks in the White Rock Formation that indicate that the basement beneath the Meguma terrane is isotopically indistinguishable from the ca. $440 \mathrm{Ma}$ Avalon terrane (Murphy et al., 1996; Keppie et al., 1997).

A connection between the Avalon and Meguma terranes extending back to the late Neoproterozoic is supported by: (1) the stratigraphic continuity (except for a minor disconformity) between the CambrianOrdovician Meguma Group and the overlying Upper Ordovician-Lower Devonian rocks (which indicates the absence of any accretionary event in the early Paleozoic); and (2) the

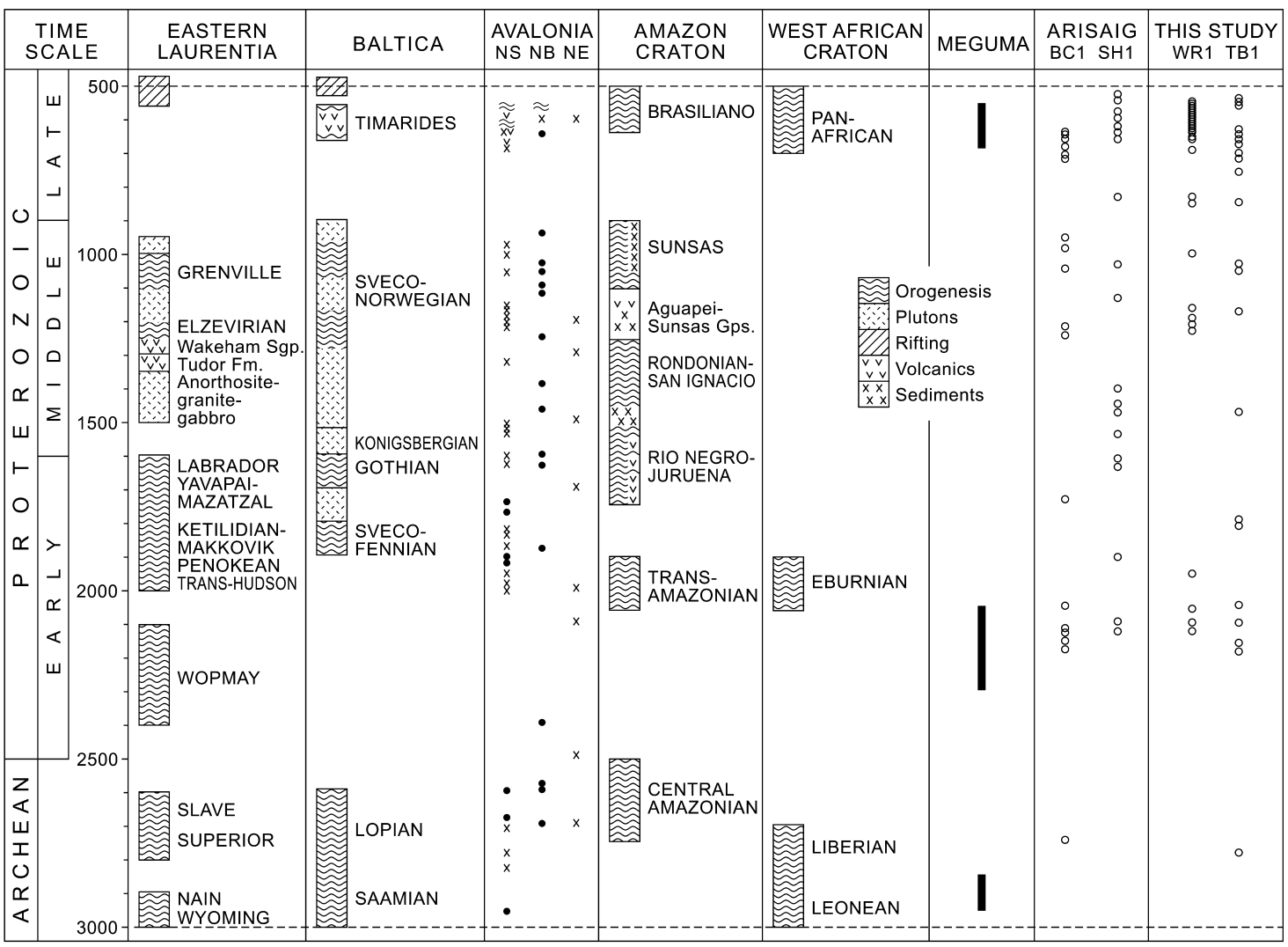

Figure 3. Detrital zircon ages (open circles) from Upper Ordovician and Lower Devonian clastic rocks in Meguma terrane (WR-10 and TB-1) and Avalon terrane (Arisaig Group, BC-1 and SH-1; Murphy et al., 2004). These data are compared with detrital zircon data from underlying Meguma Group (Krogh and Keppie, 1990) and Neoproterozoic Avalonia (Keppie et al., 1998; Bevier et al., 1990). Symbols: $x$-concordant $\mathrm{U}-\mathrm{Pb}$ zircon ages; filled circles-discordant ${ }^{207} \mathrm{~Pb} /{ }^{206} \mathrm{~Pb}$ ages. Also shown are tectonothermal events in Baltica (Gower et al., 1990; Roberts, 2003), eastern Laurentia (Cawood et al., 2001), Amazon craton (Sadowski and Bettencourt, 1996), northwest Africa (Rocci et al., 1991), and Gander (van Staal et al., 1996). NS-Nova Scotia; NB-New Brunswick; NE-New England. 
lack of any suture-zone lithologies (e.g., ophiolites) between the Meguma and Avalon terranes. Although the Meguma Group is inferred to be underlain by Avalonian basement, detrital zircon data suggest derivation of its Cambrian rocks from the West Africa craton (Fig. 3), implying lateral continuity with northern Gondwana in Cambrian time. The contrast in detrital zircon populations between Cambrian and Upper Ordovician Meguma terrane rocks is consistent with a switch in paleocurrent directions from south to north (present coordinates) (Lane, 1976; Schenk, 1997).

The early Middle Devonian zircons in TB1 are similar to the depositional age of the formation (Tucker and McKerrow, 1995). Although volcanic rocks of this age are absent in the Meguma terrane, they are present in Avalonia (Keppie et al., 1997), which could have been the source of these zircons. The ca. $440 \mathrm{Ma}$ zircon could have been derived from the underlying White Rock Formation, although ca. 440 Ma magmatism was common throughout Avalonia (see Keppie et al., 1997).

Figure 3 also illustrates the presence of 900-700 Ma detrital zircons in the Meguma and Avalonian Silurian-Lower Devonian sequences. van Staal et al. (1996) pointed out that zircons of this age are atypical of Laurentia, but may be found in the Gander zone of Newfoundland, which was adjacent to Avalonia at that time. The data presented here suggest that the Meguma and Avalon terranes should be regarded as parts of the same contiguous terrane that resided along the northern margin of the Rheic Ocean from the Early Silurian to the Early Devonian. If so, the Acadian orogeny in its type area is not due to the accretion of the Meguma terrane, and instead probably occurred in an Andean-type setting beneath the Laurentian margin. More generally, the study demonstrates the importance to tectonic syntheses of establishing the provenance of coeval sequences on neighboring terranes.

\section{ACKNOWLEDGMENTS}

Murphy acknowledges support from Natural Sciences and Engineering Research Council, Canada. Fernández-Suárez and Jeffries thank Tony Wighton for his assistance in the preparation and polishing of zircon mounts. Keppie is grateful to the Instituto de Geoloǵa at the Universidad Nacional Autónoma de México for logistical support. We thank P. Cawood, G. Gehrels, C. MacNiocaill, and R. Tucker for reviews. Contribution to International Geological Correlation Projects 453 and 497.

\section{REFERENCES CITED}

Bevier, M.L., Barr, S.M., and White, C.E., 1990, Late Precambrian U-Pb ages for the Brookville Gneiss, New Brunswick: Journal of Geology, v. 98 , p. $955-968$.

Boucot, A.J., 1975, Evolution and extinction rate controls: Amsterdam, Elsevier, 427 p.
Cawood, P.A., McCausland, P.J.A., and Dunning, G.R., 2001, Opening Iapetus: Constraints from the Laurentian margin of Newfoundland: Geological Society of America Bulletin, v. 113, p. 443-453.

Clarke, D.B., MacDonald, M.A., Reynolds, P.H., and Longstaffe, F.J., 1993, Leucogranites from the eastern part of the South Mountain batholith, Nova Scotia: Journal of Petrology, v. 34, p. 653-679.

Fernández-Suárez, J., Gutiérrez-Alonso, G., and Jeffries, T.E., 2002, The importance of alongmargin terrane transport in northern Gondwana: Insights from detrital zircon parentage in Neoproterozoic rocks from Iberia and Brittany: Earth and Planetary Science Letters, v. 204, p. 75-88.

Gower, C.F., Ryan, A.B., and Rivers, T., 1990, MidProterozoic Laurentia-Baltica: An overview of its geological evolution and summary of the contributions by this volume, in Gower, C.F., et al., eds., Mid-Proterozoic LaurentiaBaltica: Geological Association of Canada Special Paper 38, p. 1-20.

Jeffries, T., Fernández-Suárez, J., Corfu, F., and Gutiérrez Alonso, G., 2003, Advances in U-Pb geochronology using a frequency quintupled Nd:YAG based laser ablation system (lambda $=213 \mathrm{~nm}$ ) and quadrupole based ICP-MS: Journal of Analytical Atomic Spectrometry, v. 18 , p. $847-855$.

Keppie, J.D., and Krogh, T.E., 2000, 440 Ma igneous activity in the Meguma terrane, Nova Scotia, Canada: Part of the Appalachian overstep sequence?: American Journal of Science, v. 300, p. 528-538.

Keppie, J.D., Dostal, J., Murphy, J.B., and Cousens, B.L., 1997, Palaeozoic within-plate volcanic rocks in Nova Scotia (Canada) reinterpreted: Isotopic constraints on magmatic source and paleocontinental reconstructions: Geological Magazine, v. 134, p. 425-447.

Keppie, J.D., Davis, D.W., and Krogh, T.E., 1998, $\mathrm{U}-\mathrm{Pb}$ geochronological constraints on Precambrian stratified units in the Avalon composite terrane of Nova Scotia, Canada: Tectonic implications: Canadian Journal of Earth Sciences, v. 35, p. 222-236.

Keppie, J.D., Nance, R.D., Murphy, J.B., and Dostal, J., 2003, Tethyan, Mediterranean, and Pacific analogues for the NeoproterozoicPaleozoic birth and development of peri-Gondwanan terranes and their transfer to Laurentia and Laurussia: Tectonophysics, v. 365 , p. $195-219$.

Krogh, T.E., and Keppie, J.D., 1990, Age of detrital zircon and titanite in the Meguma Group, southern Nova Scotia, Canada: Clues to the origin of the Meguma terrane: Tectonophysics, v. 177 , p. $307-323$.

Lane, T.E., 1976, Stratigraphy of the White Rock Formation: Maritime Sediments, v. 12, p. 87-106.

Ludwig, K.R., 2001, Isoplot/Ex version 2.49: Berkeley Geochronology Center Special Publication $1,55 \mathrm{p}$.

MacNiocaill, C., van der Pluijm, B.A., and Van der Voo, R., 1997, Ordovician paleogeography and the evolution of the Iapetus ocean: Geology, v. 25, p. 159-162.

Murphy, J.B., Keppie, J.D., Dostal, J., Waldron, J.W.F., and Cude, M.P., 1996, Geochemical and isotopic characteristics of Early Silurian clastic sequences in Antigonish Highlands, Nova Scotia, Canada: Constraints on the accretion of Avalonia in the AppalachianCaledonide orogen: Canadian Journal of Earth Sciences, v. 33, p. 379-388.
Murphy, J.B., Fernández-Suárez, J., and Jeffries, T.E., 2004, Lithogeochemical, Sm-Nd and U$\mathrm{Pb}$ isotopic data from the Silurian-Early Devonian Arisaig Group clastic rocks, Avalon terrane, Nova Scotia: A record of terrane accretion in the Appalachian-Caledonide orogen: Geological Society of America Bulletin, v. 116 (in press).

Pratt, B.R., and Waldron, J.W.F., 1991, A Middle Cambrian trilobite faunule from the Meguma Group of Nova Scotia: Canadian Journal of Earth Sciences, v. 28, p. 1843-1853.

Roberts, D., 2003, The Scandinavian Caledonides: Event chronology, palaeogeographic settings and likely modern analogues: Tectonophysics, v. 365, p. 283-299.

Robinson, P., Tucker, R.D., Bradley, D., Berry, H.N.V., and Osberg, P.H., 1998, Paleozoic orogens in New England, USA: Geologiska Föreningens Förhandlingar, v. 120, p. 119-148.

Rocci, G., Bronner, G., and Deschamps, M., 1991 , Crystalline basement of the West African craton, in Dallmeyer, R.D., and Lecorche, J.P., eds., The West African orogens and circumAtlantic correlatives: Heidelberg, Germany, Springer-Verlag, p. 31-61.

Sadowski, G.R., and Bettencourt, J.S., 1996, Mesoproterozoic tectonic correlations between eastern Laurentia and the western border of the Amazon craton: Precambrian Research, v. 76, p. 213-227.

Schenk, P.E., 1997, Sequence stratigraphy and provenance on Gondwana's margin: The Meguma zone (Cambrian-Devonian) of Nova Scotia, Canada: Geological Society of America Bulletin, v. 109 , p. 395-409.

Tucker, R.D., and McKerrow, W.S., 1995, Early Paleozoic chronology: A review in light of new $\mathrm{U}-\mathrm{Pb}$ zircon ages from Newfoundland and Britain: Canadian Journal of Earth Sciences, v. 32 , p. $368-379$.

van Staal, C.R., Sullivan, R.W., and Whalen, J.B., 1996, Provenance and tectonic history of the Gander zone in the Caledonide/Appalachian orogen: Implications for the origin and assembly of Avalon, in Nance, R.D., and Thompson, M.D., eds., Avalonian and related periGondwanan terranes of the circum-North Atlantic: Geological Society of America Special Paper 304, p. 347-367.

van Staal, C.R., Dewey, J.F., MacNiocaill, C., and McKerrow, W.S., 1998, The CambrianSilurian tectonic evolution of the Northern Appalachians and British Caledonides: History of a complex, west and southwest Pacifictype segment of Iapetus, in Blundell, D., and Scott, A.C., eds., Lyell: The past is the key to the present: Geological Society [London] Special Publication 143, p. 199-242.

Wiedenbeck, M., Allé, P., Corfu, F., Griffin, W.L., Meier, M., Orbeli, F., von Quadt, A., Roddick, J.C., and Spiegel, W., 1995, Three natural zircon standards for U-Th- $\mathrm{Pb}, \mathrm{Lu}-\mathrm{Hf}$, trace element and REE analyses: Geostandards Newsletter, v. 19, p. 1-23.

Williams, S.H., Harper, D.A.T., Neuman, R.B., Boyce, W.D., and MacNiocaill, C., 1995, Lower Paleozoic fossils from Newfoundland and their importance in understanding the history of the Iapetus Ocean, in Hibbard, J., et al., eds.. Current perspectives in the AppalachianCaledonian orogen: Geological Association Canada Special Paper 41, p. 115-126. 